J. Product. \& Dev., 12(1): 277 - 297(2007)

\title{
EFFECT OF ANIMAL HORMONES ON THE MORPHOLOGICAL, CHEMICAL AND ANATOMINCAL STRUCTURE OF POTHOS (Scindapsus aureus) PLANT
}

\author{
Safia H. El-Hanafy.
}

Ornamental Horticulture Department, Faculty of Agriculture, Cairo University, Egypt.

\section{ABSTRACT}

Striking similarities actually exist between plant and animal tissues, as far as consideration concerns cell structure and biological processes.

Through this concept, two animal hormones were added at different concentrations to the drenching solution of pothos (Scindapsus aureus) plants, in a trial to examine their possible effects on growth and development of a representative member of the plant kingdom.

This study was conducted in the Faculty of Agriculture, Cairo University, during the two successive seasons of 2003/2004 and 2004/2005.

Three concentrations were used for an estrogenic hormone (ethinyl estradiol at $0.1,0.15$ and 0.2 ppm), two concentrations for a progestational hormone (lynestrenol at 1 and $1.5 \mathrm{ppm}$ ) and a combination of the two zoochemical agents (ethinyl estradiol at $0.1+$ lynestrenol at 1 ppm).

The plants were studied morphologically, chemically and anatomically. The morphology, included plant height, number of leaves per plant, leaf area, fresh and dry weights of leaves, main stem diameter, and its fresh and dry weights, root length, and its fresh and dry weights. Calculations were made for the stem cross-sectional area, and also for the percentage increase of the above mentioned parameters for the aboveground plant parts, in association with the most effective treatment in the study (ethinyl estradiol at 0.1 ppm) in comparison to control morphological values.

The chemical analysis included the pigment content in fresh leaves, as well as the nitrogen, phosphorus, and potassium percentages in dry leaves. The anatomical description included the laminar thickness, midrib thickness, number of vascular bundles per midrib, thickness of petiole, and the number of vascular bundles per petiole. Calculations were made for the midrib and petiole cross-sectional areas, and their vascular densities, in addition to the percentage increase of the above mentioned anatomical parameters, in association with the most effective treatment in the study (ethinyl estradiol at $0.1 \mathrm{ppm}$ ) in comparison to control anatomical values.

Statistical analysis of the results revealed a clear response to hormones in the form of considerable enhancement of plant height, as well as leaf and stem parameters. Limited increments were recorded for root parameters. Increased nitrogen and phosphorus percentages in dry leaves were also recorded.

The best enhancing effects were generally recorded with ethinyl estradiol at 0.1 ppm.. It can be concluded that estrogen, may represent a 
form of exogenous biological growth regulator in the field of plant promotion. These enhancing effects might be explained by the presence of estrogen receptors (already confirmed in literature) and /or progesterone receptors in plant tissue. Alternatively, animal hormones may be inducing plant cytokinins, or else performing cytokinin-like action (morphogenesis).

Further experimental studies, may be recommended, such as using lower concentrations of these hormones, and comparing drenching to spraying, in addition to manipulating the plants differently as regards fertilization, and comparison of animal hormones with other known growth regulators. These zoochemical agents may prove to be beneficial in induction of plant tissue culture. However, the life time duration of treated plants should be studied in the presence of such hormones. The plant tissue content of these hormones and their degradation products, should also be estimated, as they may, later on, be used for increasing the production of edible, medicinal, or aromatic plants, with subsequent possible effects on human health.

Key words: Plant, pothos, estrogen, progesterone .

\section{INTRODUCTION}

The two main kingdoms of life are those of plants and animals. A great similarity exists between plant and animal cell structures. There is, therefore, similarity between the biological processes in the two cell types. A high analogy, for example, may exist between the amino acid sequence of plant and animal genes, with their structural features, main chain conformation and folding patterns being greatly similar (Yao and Liu 2005). In addition, the stability and physical behaviour of liposomes, common to plant and animal cells are similarly affected by sugar and lipid metabolites (Dirk et al, 2006).

Cytokinesis events are mediated in plant cells by the phragmoplast, and in animal cells by the spindle midzone /midbody, with the increasing number of discovered similarities, suggesting that they might be analogous structures (Marisa et al, 2005; and Michiko and Machida, 2006). Micro RNAs are regulatory RNA molecules, recently described in plant and animal cells that regulate gene transcription through the biogenesis mechanisms (Xiao and Zhang, 2005; and Narry and Nam, 2006). Common gene promoters involved in DNA replication were also described (Tamas et al, 2005). Peter et al (2005) confirmed the similarity between the embryonic development of plants and that of animals, both of which exhibiting identical strict coordination of cell proliferation, differentiation and death programs.

In the basics of innate immune response, remarkable similarity exists between plant and animal kingdoms (Lourdes, 2004). The antimicrobial peptides (AMPs) common to plant and animal cells are an important component of the natural defences against invading pathogens (Reddy et al, 2004).

In the field of plant protoplast cell culture, novel approaches to maximize the efficacy of protoplast-to-plant systems include techniques already well-established for animal cells such as electro stimulation, exposure to surfactant and respiratory gas carriers, especially perfluoro chemicals and haemoglobin (Michael, 2005). 
Plant genomes encode large numbers of receptor kinesis that are structurally related to the tyrosine and serine / threonine families of receptor kinas found in animals. Plant and animal receptor kinas share many common features, such as their single membrane-pass structure, their inclusion in membraneassociated complexes, the involvement of dimerisation and transautophosphorylation in receptor activation, and the existence of inhibitors and phosphatises that down-regulate receptor activity. These points of convergence may represent features that are essential for a functional receptor-kinas signalling system (Mark et al, 2002).

There is now a well-known common area of genetic basis of diseases in plants and animals, with the recent discovery of remedial genetic agents common to both kingdoms (Zhuang and Mahajan, 2005).

The synthesis of steroid hormones in different plant species, and the possibility that these molecules could regulate cell growth, tissue differentiation and germination has been reported. However, the mechanism of action of these endogenous steroids in plant cells is still poorly understood. Estrogen-binding sites and estrogen-like compounds were detected in lipid extracts of Solanum glaucophyllum and Lycopersicon esculentum organs. these results provide evidence about the existence of estrogen-binding proteins and endogenous ligands in Solanaceae (Lorena and Boland, 2004).

Phytoestrogens derived from plants (especially soy products), are molecules structurally and functionally similar to estradiol, with genistein and coumesterol being examples of them (Torres, 2002 and Lephart et al, 2003).

Estrogen and progesterone hormones are widely used zoochemical steroids in the field of animal wealth development. Those female animal ovarian steroids have important inter-related roles in many systems and processes required for mammalian reproduction (Sylvia and Korach, 2000). In this study, two animal hormones; ethinyl estradiol (estrogenic) and lynestrenol (progestational), were used for drenching of Scindapsus aureus, with the aim of exploring their effects in the plant kingdom, taking into consideration the hypothesis that, the presence of estrogen and/or progesterone receptors in plants, would be associated with possible improvement in plant characters and/or induction of growth. The main build-up of estrogen and progesterone is represented by the steroid nucleus, which is also common to other different sterols like vitamin $\mathrm{D}$ (Mathew et al, 2005). Vitamin $\mathrm{D}_{3}$ sterols and stigmasterol were previously used in-vitro to stimulate root cell division in plant tissue culture, with positive results (Talmon et al, 1989).

\section{MATERIALS AND METHODS}

This study was conducted in a glasshouse in the Experimental Nursery of the Ornamental Horticulture Department, Faculty of Agriculture, Cairo University, during the two successive seasons of 2003/2004 and 2004/2005.

Terminal cuttings of the perennial foliage plant, Scindapsus aureus (each having 4 leaves, and was $15 \mathrm{~cm}$ high), were planted on Nov. $1^{\text {st }} 2003$ and 2004 (in the first and second seasons, respectively) in $20 \mathrm{~cm}$ diameter plastic pots filled with 1:1:1(by volume) mixture of sand, peat moss and perlite, at a rate of one plant per pot. The plants were divided into 7 groups, each consisting of 18 plants. 
Drenching solutions were prepared using an estrogenic hormone (ethinyl estradiol) at concentrations of $0.1,0.15$ and $0.2 \mathrm{ppm}$, a progestational hormone (lynestrenol) at 1 and $1.5 \mathrm{ppm}$, and a combination of ethinyl estradiol at $0.1 \mathrm{ppm}+$ lynestrenol at $1 \mathrm{ppm}$, thus forming 6 treatment groups, to be compared to a cotrol group of plants receiving no hormones.

Treatment started one month after planting. Drenching was then applied for the treatment groups every 21 days, and repeated 8 times in each season. All other regular agricultural practices were similar in all plants, including complete chemical fertilization with Kristalon containing N: P: K: Mg $\quad(19 ; 19: 19: 2)$, at the rate of $1 \mathrm{~g} /$ plant every 3 weeks. The experiment was ended in both seasons by the beginning of June (2004 and 2005 in the first and second seasons).

The plants were studied morphologically, chemically and anatomically. The morphology, included plant height $(\mathrm{cm})$, number of leaves per plant, $5^{\text {th }}$ leaf (counted from the base) surface area $\left(\mathrm{cm}^{2}\right)$, fresh and dry weights of leaves per plant $(\mathrm{g})$, main stem diameter $(\mathrm{cm})$, fresh and dry weights of the main stem $(\mathrm{g})$, root length $(\mathrm{cm})$, and fresh and dry weights of roots per plant $(\mathrm{g})$. Calculations were made for the stem cross-sectional area $\left(\mathrm{mm}^{2}\right)$, and also for the percentage increase of the above mentioned parameters for the above-ground plant parts, in association with the most effective treatment in the study (ethinyl estradiol at 0.1 ppm) in comparison to control morphological values.

The calculation of the cross-sectional area of the stem was done by using the following equation:

Surface area of a circle $=\pi r^{2}$

Where $\pi$ is the approximate ratio 3.14 and $\mathrm{r}$ is the radius. The stem diameter $=2 \mathrm{r}$.

The percentage increase in any of the parameters of the above-ground parts was calculated from the following equation:

Percentage increase $=$

The mean value of treated plants - The mean value of control X 100 The mean value of control

The chemical analysis included the pigment content of chlorophyll a, chlorophyl $\mathrm{b}$ and carotenoids $(\mathrm{mg} / \mathrm{gm}$ ) in fresh leaves (a method of estimation according to Saric et al, 1976), and nitrogen, phosphorus and potassium in dry leaves. Nitrogen was estimated by Nesslar method according to the procedure of A.O.A.C. (1960). Phosphorus was determined according to Troug and Meyer (1939). Potassium was determined by using Flame Photometer 410 (Dewis and Freitas, 1970).

The anatomical manipulation of the plants started at the age of 200 days, where the median leaf (blade and petiole) of one plant from each replicate was killed and fixed for at least 48 hours in F.A.A. (10 ml. of formalin, $5 \mathrm{ml}$ of glacial acetic acid and $85 \mathrm{ml}$ of $70 \%$ ethyl alcohol). Fixed materials were washed in $50 \%$ ethyl alcohol, dehydrated in a normal butyl alcohol series, and embedded in paraffin wax with a melting point of $52-54{ }^{\circ} \mathrm{C}$. Sections of $15-20 \mu$-thicks were cut by the microtome. Safranin \& fast green combination method (Sass, 1961) was used for staining; stained sections were cleared in xylene and mounted in Canada balsam (Willey, 1971).

The anatomical description included the laminar thickness $(\mu)$, midrib thickness $(\mu)$, number of vascular bundles /midrib, thickness of petiole $(\mu)$, and number of vascular bundles /petiole. Calculations were made for the midrib and 
petiole cross-sectional areas $\left(\mathrm{mm}^{2}\right.$ ), and their vascular densities (number of vascular bundles per unit cross-sectional area for a midrib or a petiole), in addition to the percentage increase of the above mentioned anatomical parameters, in association with the most effective treatment in the study (ethinyl estradiol at 0.1 $\mathrm{ppm}$ ), in comparison to control anatomical values. equation:

The calculation of cross-sectional area was done by using the following

Where $\pi$ is the approxinate

Surface area of a circle $=\pi r^{2}$
te ratio 3.14 and $\mathrm{r}$ is the radius.

The thickness of the midrib or petiole was used in this equation as being equal to $2 \mathrm{r}$ (i.e. the diameter of the midrib or petiole).

The density of vascular bundles in the midrib, or in the petiole (number of bundles per unit area of the cross-section), was calculated from the following equation:

Density of vascular bundles $=$ Number of vascular bundles in the structure Cross-sectional area of the structure

The percentage increase in any of the parameters of the above-ground parts was calculated from the following equation:

Percentage increase $=$ The mean value of treated plants - The mean value of control $x 100$

\section{The mean value of control}

The design for this experiment was complete randomized design (CRD) with three replicates. Data were statistically analyzed with the Analysis of Variance (ANOVA) according to Snedecor and Cochran (1980) using Mstatc program. When significant differences $(\mathrm{P}<0.05)$ were detected, the least significant difference (LSD) test was used to separate the mean values according to Steel and Torrie (1981).

\section{RESULTS AND DISCUSSION}

\section{Plant morphology (Tables 1and 2):}

\subsection{Plant height (cm)}

Data presented in Table 1 reveal a significant increase of plant height with all treatments in both seasons, compared to the control. Ethinyl estradiol at the lowest concentration $(0.1 \mathrm{ppm})$ was associated with the highest increase of plant height in both seasons ( 94.22 compared to $65.63 \mathrm{~cm}$ in the first season, and 121.10 compared to $74.32 \mathrm{~cm}$ in the second season).

\subsection{Leaf parameters:}

\subsubsection{Number of leaves / plant:}

Table 1 shows that, all treatments induced a significant increase in the number of leaves/plant in both seasons, compared to the control. Ethinyl estradiol at the lowest concentration $(0.1 \mathrm{ppm})$ was associated with the highest increase in both seasons (17.43 compared to 10.57 leaves /plant in the first season, and 22.17 compared to 13.44 leaves /plant in the second season).

\subsubsection{Leaf area $\left(\mathrm{cm}^{2}\right)$}

A prominent increase in leaf area is very obvious through Table 1, with the increase being significant with all treatments in both seasons. The average leaf area 
of treated plants approached, in some results, double that of the control. Again, the lowest concentration of Ethinyl estradiol $(0.1 \mathrm{ppm})$ was associated with the highest increase in both seasons, being almost 3 times that of the control (78.85 compared to $29.07 \mathrm{~cm}^{2}$ in the first season, and 91.5 compared to $33.12 \mathrm{~cm}^{2}$ in the second season).

\subsubsection{Fresh weight of leaves (g)}

Table 1 shows that, both seasons were associated with significant increments in fresh weight with all treatments, particularly with the first drenching solution (containing ethinyl estradiol at $0.1 \mathrm{ppm}$ ) which gave an average fresh weight of 33.71 versus $13.17 \mathrm{~g}$ in the first season, and 40.02 versus $16.18 \mathrm{~g}$ in the second, compared to the control.

\subsubsection{Dry weight of leaves (gm)}

Dry weight changes had almost the same trend as that of fresh weight. Table 1 reveals a significant increase with all treatments in the first season, and with five of the six treatments in the second season. However, the highest average increments in both seasons were recorded with the first treatment of $0.1 \mathrm{ppm}$ ethinyl estradiol (9.90 versus 3.94 in the first season, and 8.48 versus $3.36 \mathrm{~g}$ in the second, compared to the control).

It should be noticed from Table 1 that, the first treatment (ethinyl estradiol at the concentration of $0.1 \mathrm{ppm}$ ) gave increments in leaf area and leaf weights that are significantly higher than all other treatments.

Table 1. Morphological changes including plant height $(\mathrm{cm})$, number of leaves / plant, leaf area and fresh and dry weights of leaves in the first and second seasons in response to animal hormones.

\begin{tabular}{|c|c|c|c|c|c|c|c|c|c|c|}
\hline \multirow[t]{2}{*}{$\begin{array}{l}\text { Treatme } \\
\text { nts } \\
\text { (ppm) }\end{array}$} & \multicolumn{2}{|c|}{$\begin{array}{l}\text { Plant height } \\
\text { (cm) }\end{array}$} & \multicolumn{2}{|c|}{$\begin{array}{l}\text { No. of leaves } \\
\text { /plant }\end{array}$} & \multicolumn{2}{|c|}{$\begin{array}{c}\text { Leafarea } \\
\left(\mathrm{cm}^{2}\right)\end{array}$} & \multicolumn{2}{|c|}{$\begin{array}{l}\text { Fresh weight of } \\
\text { leaves } \\
\text { (g) }\end{array}$} & \multicolumn{2}{|c|}{$\begin{array}{c}\text { Dry weight of } \\
\text { leaves } \\
\text { (g) }\end{array}$} \\
\hline & $1^{\mathrm{st}}$ & $2^{\text {nd }}$ & $1^{\mathrm{st}}$ & $2^{\text {nd }}$ & $1^{s t}$ & $2^{\text {nd }}$ & $1^{\text {st }}$ & $2^{\text {nd }}$ & $1^{\mathbf{s}}$ & $2^{\text {nd }}$ \\
\hline Control & $65.63 \mathrm{e}$ & $74.32 \mathrm{~d}$ & $10.57 \mathrm{~d}$ & $13.44 d$ & $29.07 \mathrm{f}$ & $33.12 \mathrm{~g}$ & $13.17 \mathrm{e}$ & $16.18 \mathrm{e}$ & $3.94 \mathrm{~d}$ & $3.36 \mathrm{e}$ \\
\hline E.E. 0.1 & $94.22 \mathrm{a}$ & $121.10 \mathrm{a}$ & $17.43 \mathrm{a}$ & $22.17 \mathrm{a}$ & $78.85 a$ & $91.50 \mathrm{a}$ & $33.71 \mathrm{a}$ & $40.02 \mathrm{a}$ & $9.90 \mathrm{a}$ & $8.48 \mathrm{e}$ \\
\hline E.E. 0.15 & $75.15 d$ & $103.7 \mathrm{bc}$ & $13.68 \mathrm{c}$ & $17.42 \mathrm{c}$ & $51.92 \mathrm{e}$ & $58.72 \mathrm{e}$ & $20.06 \mathrm{~d}$ & $23.69 \mathrm{~cd}$ & $5.24 c$ & $4.56 \mathrm{de}$ \\
\hline E.E. 0.2 & $86.11 \mathrm{bc}$ & $108.5 b$ & $15.67 \mathrm{ab}$ & $18.85 \mathrm{~b}$ & $61.72 \mathrm{~b}$ & $64.61 \mathrm{~b}$ & $29.36 \mathrm{~b}$ & $28.84 b c$ & $6.73 b$ & $6.82 \mathrm{~b}$ \\
\hline Lyn. 1 & $82.20 \mathrm{c}$ & $100.7 \mathrm{c}$ & $15.01 \mathrm{bc}$ & $16.39 \mathrm{c}$ & $53.42 d$ & $57.33 \mathrm{f}$ & $24.26 \mathrm{c}$ & $24.02 \mathrm{bcd}$ & $5.19 \mathrm{c}$ & $5.27 \mathrm{~cd}$ \\
\hline Lyn. 1.5 & 92.31ab & $116.2 \mathrm{a}$ & $16.48 \mathrm{ab}$ & $21.35 \mathrm{a}$ & $57.50 \mathrm{c}$ & $62.14 c$ & $26.41 \mathrm{c}$ & $27.01 \mathrm{~b}$ & $7.04 \mathrm{~b}$ & $6.44 \mathrm{bc}$ \\
\hline $\begin{array}{l}\text { E.E. } 0.1 \\
+ \text { Lyn. } 1 \\
\end{array}$ & $92.40 \mathrm{a}$ & $98.4 \mathrm{c}$ & $16.80 \mathrm{ab}$ & $17.02 \mathrm{c}$ & $53.40 \mathrm{~d}$ & $60.47 \mathrm{~d}$ & $24.33 \mathrm{c}$ & $22.64 d$ & $5.21 \mathrm{c}$ & $5.60 \mathrm{bcd}$ \\
\hline LSD & 6.285 & 7.241 & 1.884 & 1.365 & 0.759 & 0.709 & 2.699 & 5.141 & 0.809 & 1.287 \\
\hline
\end{tabular}

Means with different letters within each column are significant $(\mathrm{P}<0.05$.) level and means without letters are not significant.

$\mathrm{LSD}=$ Least significant difference at $5 \%$, No. $=$ Number $\quad$ E.E. $=$ Ethinyl estradiol Lyn.

$=$ Lynestrenol 


\subsection{Main stem parameters (Table, 2) \\ 1.3.1.Stem diameter $(\mathrm{cm})$}

The same trend was confirmed by the data in Table 2, where all hormonal doses significantly increased the stem diameter in both seasons, in comparison to the control. The lowest dose of ethinyl estradiol $(0.1 \mathrm{ppm})$, was the most effective in both seasons, in comparison to the control $(0.95$ versus $0.60 \mathrm{~cm}$ for the first, and 1.21 versus $0.62 \mathrm{~cm}$ for the second season). Doubling of the stem diameter was thus, noted with the first treatment in the second season.

\subsubsection{Stem fresh weight (g)}

The results here coincide with the above-mentioned results, where all hormonal doses significantly increased the stem fresh weight in both seasons, in comparison to the control.

The lowest dose of ethinyl estradiol $(0.1 \mathrm{ppm})$, was again the most effective in both seasons in comparison to the control (19.05 versus $10.34 \mathrm{~g}$ for the first, and 18.33 versus $9.90 \mathrm{~g}$ for the second season). Doubling of the stem fresh weight was evident with the first treatment in both seasons.

Table 2. Morphological changes including the main stem diameter, and stem fresh and dry weights of pothos plants in the first and second seasons in response to animal hormones.

\begin{tabular}{lcccccc}
\hline \multirow{2}{*}{$\begin{array}{l}\text { Treatments } \\
(\mathbf{p p m})\end{array}$} & \multicolumn{2}{c}{ Stem diameter $(\mathbf{c m})$} & \multicolumn{2}{c}{ Stem F.W. $(\mathbf{g})$} & \multicolumn{2}{c}{ Stem D.W. $(\mathbf{g})$} \\
\cline { 2 - 7 } & $1^{\text {st }}$ & $\mathbf{2}^{\text {nd }}$ & $\mathbf{1}^{\text {st }}$ & $\mathbf{2}^{\text {nd }}$ & $\mathbf{1}^{\text {st }}$ & $\mathbf{2}^{\text {nd }}$ \\
\hline Control & $0.60 \mathrm{f}$ & $0.62 \mathrm{e}$ & $10.34 \mathrm{e}$ & $9.90 \mathrm{c}$ & $2.86 \mathrm{~d}$ & $2.74 \mathrm{e}$ \\
E.E. 0.1 & $0.95 \mathrm{a}$ & $1.21 \mathrm{a}$ & $19.05 \mathrm{a}$ & $18.33 \mathrm{a}$ & $5.40 \mathrm{a}$ & $5.19 \mathrm{a}$ \\
E.E. 0.15 & $0.81 \mathrm{bc}$ & $0.75 \mathrm{~d}$ & $15.30 \mathrm{c}$ & $15.49 \mathrm{~b}$ & $3.10 \mathrm{~cd}$ & $3.14 \mathrm{de}$ \\
E.E. 0.2 & $0.85 \mathrm{~b}$ & $0.90 \mathrm{~b}$ & $17.10 \mathrm{~b}$ & $16.25 \mathrm{~b}$ & $4.10 \mathrm{~b}$ & $3.99 \mathrm{bc}$ \\
Lyn. 1 & $0.71 \mathrm{e}$ & $0.80 \mathrm{~cd}$ & $13.18 \mathrm{~d}$ & $14.81 \mathrm{~b}$ & $2.98 \mathrm{~d}$ & $3.35 \mathrm{cde}$ \\
Lyn. 1.5 & $0.75 \mathrm{de}$ & $0.89 \mathrm{bc}$ & $13.29 \mathrm{~d}$ & $14.89 \mathrm{~b}$ & $3.09 \mathrm{~cd}$ & $3.46 \mathrm{bcd}$ \\
E.E. 0.1+Lyn. 1 & $0.77 \mathrm{~cd}$ & $0.90 \mathrm{~b}$ & $13.63 \mathrm{~d}$ & $16.30 \mathrm{~b}$ & $3.41 \mathrm{c}$ & $4.03 \mathrm{~b}$ \\
\hline LSD at & $\mathbf{0 . 0 5 6}$ & $\mathbf{0 . 0 9 7}$ & $\mathbf{1 . 5 8 5}$ & $\mathbf{1 . 6 1 4}$ & $\mathbf{0 . 3 9 0}$ & $\mathbf{0 . 6 6 8}$ \\
$\mathbf{0 . 0 5}$ & & & & & & \\
\hline
\end{tabular}

Means with different letters within each column are significant at $\mathrm{P}<0.05$ level and means without letters are not significant. LSD $=$ Least significant difference

E.E. $=$ Ethinyl estradiol $\quad$ Lyn. $=$ Lynestrenol $\quad$ F.W. $=$ Fresh weight $\quad$ D.W. $=$ Dry weight

\subsubsection{Stem dry weight (g)}

As shown in Table 2, the dry weight changes were parallel to fresh weight changes, as well as to other changes, where significant increments were recorded with all hormonal drenches in both seasons. Not only this, but also the lowest concentration of ethinyl estradiol $(0.1 \mathrm{ppm})$ representing the first treatment, was the most effective dose in dry weight induction, in comparison to the control in both seasons (5.40 versus $2.86 \mathrm{~g}$ in the first season, and 5.19 versus $2.74 \mathrm{~g}$ in the second). This treatment, thus almost doubled the dry weight of the control in both seasons. 
Thus, all of the above-mentioned results, including the plant height, as well as the leaf and stem parameters, demonstrated, in a regular way, significant increments, with both types of hormones, at their different concentrations, and also with their combination, in both seasons, in comparison to the control. Ethinyl estradiol at the concentration of $0.1 \mathrm{ppm}$ was also regularly, the most effective treatment in all the above-ground plant parameters in both seasons, in comparison to other treatments. With this concentration, the results were sometimes double, or even triple those of the control.

A better realization of improvement of stem biomass with this concentration was done by comparing the cross-sectional area of the stem in treated plants, and that of the control.

Since the best results for the above-ground parts in this study were regularly recorded with ethinyl estradiol at $0.1 \mathrm{ppm}$, Table 3 shows the percentage increase in different morphological parameters with this particular treatment.

Table 3. Percentage increase in different morphological parameters with ethinyl estradiol at $0.1 \mathrm{ppm}$, based on the mean values of control pothos plants, in the first and second seasons.

\begin{tabular}{|c|c|c|c|c|c|c|}
\hline \multirow[t]{2}{*}{ Characters } & \multicolumn{3}{|c|}{ First season } & \multicolumn{3}{|c|}{ Second season } \\
\hline & Control & $\begin{array}{c}\text { E.E. at } 0.1 \\
\text { ppm }\end{array}$ & $\begin{array}{c}\text { Increase } \\
\%\end{array}$ & Control & $\begin{array}{c}\text { E.E. at 0.1 } \\
\text { ppm }\end{array}$ & $\begin{array}{c}\text { Increase } \\
\%\end{array}$ \\
\hline Plant height cm & 65.63 & 94.22 & 43.56 & 74.32 & 121.10 & 62.94 \\
\hline Stem CSA cm ${ }^{2}$ & 0.28 & 0.71 & 153.57 & 0.30 & 1.15 & 283.33 \\
\hline Stem F.W.g & 10.34 & 19.05 & 84.24 & 9.90 & 18.33 & 85.15 \\
\hline Stem D.W.g & 2.86 & 5.40 & 88.81 & 2.74 & 5.19 & 89.42 \\
\hline Number of leaves/plant & 10.57 & 17.43 & 64.9 & 13.44 & 22.17 & 64.69 \\
\hline Leaf area $\mathrm{cm}^{2}$ & 29.07 & 78.85 & 165.49 & 33.12 & 91.50 & 176.27 \\
\hline leaves F.W.g & 13.17 & 33.71 & 146.06 & 16.18 & 40.02 & 147.03 \\
\hline leaves D.Wg & 3.94 & 9.90 & 151.27 & 3.36 & 8.48 & 152.38 \\
\hline
\end{tabular}

\subsection{Root parameters (Table 4) \\ 1.4.1.Root length (cm)}

All treatments in both seasons showed increased results, in comparison to the control, with the statistical significance of the increments, being regular in the second season, and irregular (sometimes absent) in the first. In comparing the different treatments together, the first treatment (ethinyl estradiol at $0.1 \mathrm{ppm}$ ) was significantly more effective than others, in the second season.

\subsubsection{Fresh weight of roots $(g)$}

All treatments showed higher results in both seasons, compared to the control, with the increments being regularly significant in the second season. The differences between the results of different treatments, showed irregular significance in both seasons. 
Table 4. Morphological changes including root length $(\mathrm{cm})$, and fresh and dry weights of root $(\mathrm{g})$ of pothos plants, in first and second seasons, in response to animal hormones.

\begin{tabular}{lcccccc}
\hline Treatments & \multicolumn{2}{c}{ Root length $(\mathbf{c m})$} & \multicolumn{2}{c}{ Root F.W. $(\mathbf{g})$} & \multicolumn{2}{c}{ Root D.W. $(\mathbf{g})$} \\
\cline { 2 - 7 }$(\mathbf{p p m})$ & $\mathbf{1}^{\text {st }}$ & $\mathbf{2}^{\text {nd }}$ & $\mathbf{1}^{\text {st }}$ & $\mathbf{2}^{\text {nd }}$ & $\mathbf{1}^{\text {st }}$ & $\mathbf{2}^{\text {nd }}$ \\
\hline Control & $19.27 \mathrm{c}$ & $16.31 \mathrm{c}$ & $4.20 \mathrm{c}$ & $5.38 \mathrm{c}$ & $2.22 \mathrm{c}$ & 2.84 \\
E.E. 0.1 & $24.33 \mathrm{a}$ & $24.46 \mathrm{a}$ & $7.24 \mathrm{a}$ & $8.37 \mathrm{a}$ & $3.91 \mathrm{a}$ & 4.52 \\
E.E. 0.15 & $25.00 \mathrm{a}$ & $18.91 \mathrm{~b}$ & $6.27 \mathrm{ab}$ & $7.55 \mathrm{ab}$ & $3.26 \mathrm{abc}$ & 3.93 \\
E.E. 0.2 & $20.20 \mathrm{c}$ & $18.58 \mathrm{~b}$ & $5.07 \mathrm{bc}$ & $6.90 \mathrm{~b}$ & $2.58 \mathrm{bc}$ & 3.52 \\
Lyn.1 & $20.75 \mathrm{bc}$ & $20.43 \mathrm{~b}$ & $5.10 \mathrm{bc}$ & $7.94 \mathrm{ab}$ & $2.25 \mathrm{c}$ & 3.50 \\
Lyn. 1.5 & $23.16 \mathrm{ab}$ & $19.74 \mathrm{~b}$ & $6.99 \mathrm{a}$ & $8.30 \mathrm{a}$ & $3.03 \mathrm{abc}$ & 4.38 \\
E.E. 0.1+ Lyn.1 & $23.71 \mathrm{a}$ & $20.40 \mathrm{~b}$ & $6.87 \mathrm{a}$ & $7.20 \mathrm{ab}$ & $3.63 \mathrm{ab}$ & 4.15 \\
\hline LSD at 0.05 & $\mathbf{2 . 5 8 8}$ & $\mathbf{2 . 0 5 9}$ & $\mathbf{1 . 5 9 4}$ & $\mathbf{1 . 3 3 4}$ & $\mathbf{1 . 0 4 8}$ & N.S. \\
\hline
\end{tabular}

Means with different letters within each column are significant at $\mathrm{P}<0.05$ level and means without letters are not significant. LSD $=$ Least significant difference E.E. $=$ Ethinyl estradiol Lyn. $=$ Lynestrenol $\quad$ F.W.=Fresh weight $\quad$ D.W.=Dry weight

\subsubsection{Dry weight of roots (gm)}

The first season showed increments in all treatments, but with irregular significance in comparison to the control. However, increments were recorded with all hormonal treatments in the second season, with none of them being significant in comparison to the control.

The general results of root changes demonstrate limited response to different hormonal treatments, which may be representing just a harmony from the root towards the shoot, and not an actual stimulation of estrogen or progesterone receptors, or any other possible mechanism of proliferation in the roots. Generally speaking, stimulation of plant tissue growth is always demonstrated at the shoot. Lenka et al (2006) confirmed that, biomass growth under conditions of eutrophic treatment in Typha angustifolia was mainly located at the shoot rather than the root. It should be noted here that, the animal hormones in this experiment were added as a drench to soil, with their expected upward transportation, being along the transpiration current.

\section{Chemical constituents in leaves (Tables 5 and 6 )}

\subsection{Pigments in fresh leaves (Table 5)}

\subsubsection{Chlorophyll a ( $\mathrm{mg} / \mathrm{g}$ F.W.)}

The leaf content of chlorophyll a showed no clear demarcation between the control and different treatments. The highest chlorophyll a content was associated with the highest concentration of ethinyl estradiol $(0.2 \mathrm{ppm})$ in both seasons, with the increment above the control being insignificant in the first season $(0.67$ versus $0.66 \mathrm{mg} / \mathrm{g}$ F.W.), and significant in the second ( 0.78 versus $0.68 \mathrm{mg} / \mathrm{g}$ F.W.). 


\subsubsection{Chlorophyll b (mg/g F.W.)}

As in chlorophyll a, no clear trend was noted between different treatments including the control. The higher concentration of lynestrenol (1.5 ppm) gave the most prominent chlorophyll $\mathrm{b}$ content, in both seasons, compared to the control ( 0.58 versus $0.39 \mathrm{mg} / \mathrm{g} \mathrm{F.W}$. in the first season, and 0.51 versus $0.37 \mathrm{mg} / \mathrm{g} \mathrm{F.W}$. in the second).

\subsubsection{Carotenoids (mg/g F.W.)}

Similar to chlrophylls, no prominent differences were recorded between different treatments including the control. As in chlorophyll a, The highest carotenoid

Table 5. Chemical constituents: pigment content in fresh leaves (mg/g F.W.) of pothos plants in response to animal hormones in the first and second seasons

\begin{tabular}{lcccccc}
\hline \multirow{2}{*}{$\begin{array}{l}\text { Treatments } \\
\text { ppm) }\end{array}$} & \multicolumn{2}{c}{ Chlorophyll a } & \multicolumn{2}{c}{ Chlorophyll b } & \multicolumn{2}{c}{ Carotenoids } \\
\cline { 2 - 7 } $\mathbf{1}^{\text {st }}$ & $\mathbf{2}^{\text {nd }}$ & $\mathbf{1}^{\text {st }}$ & $\mathbf{2}^{\text {nd }}$ & $\mathbf{1}^{\text {st }}$ & $\mathbf{2}^{\text {nd }}$ \\
\hline Control & $0.66 \mathrm{a}$ & $0.68 \mathrm{~b}$ & $0.39 \mathrm{~d}$ & 0.37 & $0.51 \mathrm{~d}$ & $0.53 \mathrm{~d}$ \\
E.E. 0.1 & $0.56 \mathrm{c}$ & $0.62 \mathrm{c}$ & $0.40 \mathrm{~cd}$ & 0.44 & $0.59 \mathrm{bc}$ & $0.58 \mathrm{~b}$ \\
E.E. 0.15 & $0.60 \mathrm{bc}$ & $0.63 \mathrm{c}$ & $0.42 \mathrm{bc}$ & 0.43 & $0.57 \mathrm{c}$ & $0.56 \mathrm{bc}$ \\
E.E. 0.2 & $0.67 \mathrm{a}$ & $0.78 \mathrm{a}$ & $0.39 \mathrm{~d}$ & 0.41 & $0.63 \mathrm{a}$ & $0.61 \mathrm{a}$ \\
Lyn. 1 & $0.62 \mathrm{ab}$ & $0.44 \mathrm{~d}$ & $0.43 \mathrm{~b}$ & 0.40 & $0.60 \mathrm{~b}$ & $0.54 \mathrm{~cd}$ \\
Lyn. 1.5 & $0.43 \mathrm{~d}$ & $0.40 \mathrm{e}$ & $0.58 \mathrm{a}$ & 0.51 & $0.45 \mathrm{e}$ & $0.41 \mathrm{e}$ \\
E.E. 0.1 + Lyn. 1 & $0.60 \mathrm{bc}$ & $0.70 \mathrm{~b}$ & $0.39 \mathrm{~d}$ & 0.42 & $0.61 \mathrm{ab}$ & $0.58 \mathrm{~b}$ \\
\hline LSD at 0.05 & $\mathbf{0 . 0 5 6}$ & $\mathbf{0 . 0 2 8}$ & $\mathbf{0 . 0 2 3}$ & $\mathbf{N . S .}$ & $\mathbf{0 . 0 2 8}$ & $\mathbf{0 . 0 2 3}$ \\
\hline
\end{tabular}

Means with different letters within each column are significant at $\mathrm{P}<0.05$ level and means without letters are not significant. LSD = Least significant difference

E.E. $=$ Ethinyl estradiol $\quad$ Lyn. $=$ Lynestrenol $\quad$ F.W. $=$ Fresh weight

content was associated with the highest concentration of ethinyl estradiol $(0.2$ $\mathrm{ppm})$, where the increment above the control was significant in both seasons $(0.63$ versus $0.51 \mathrm{mg} / \mathrm{g}$ F.W. in the first season, and 0.61 versus $0.53 \mathrm{mg} / \mathrm{g} \mathrm{F.W.} \mathrm{in} \mathrm{the}$ second).

\subsection{Nitrogen, phosphorus and potassium percentages in dry leaves}

\subsubsection{Nitrogen percentage (Table 6)}

In both seasons, the first treatment (ethinyl estradiol at $0.1 \mathrm{ppm}$ ) showed significantly higher results compared to the control. Otherwise, other treatments in both seasons were associated with irregular results (higher or lower) compared to the control. This increased nitrogen percentage associated with the first treatment, may be explained by the cytoplasmic accumulation of nitrogen-containing row substrate, ribosomal proteins, cytokinins and phragmoplast, which are known in literature to be involved in cellular proliferation (Marisa et al, 2005 and Michiko and Machida, 2006). 


\subsubsection{Phosphorus percentage (Table 6)}

The same trend of results recorded with nitrogen percentage, was noticed with that of phosphorus, where in both seasons, the first treatment (ethinyl estradiol at $0.1 \mathrm{ppm}$ ) showed significantly higher results compared to the control. Otherwise, other treatments in both seasons were associated with irregular results (higher or lower) compared to the control. The detected parallelism between the trends of nitrogen and phosphorus changes, may be explained by their being important participants in the process of protein synthesis associated with morphogenesis (Xiao and Zhang, 2005).

Table 6. Chemical constituents: N., P., and K. \% in dry leaves of pothos plants in response to animal hormones in the first and second seasons

\begin{tabular}{|c|c|c|c|c|c|c|}
\hline \multirow{2}{*}{$\begin{array}{c}\text { Treatments } \\
\text { (ppm) }\end{array}$} & \multicolumn{2}{|c|}{ Nitrogen } & \multicolumn{2}{|c|}{ Phosphorus } & \multicolumn{2}{|c|}{ Potassium } \\
\hline & $1^{\text {st }}$ & $2^{\text {nd }}$ & $1^{\text {st }}$ & $2^{\text {nd }}$ & $1^{\text {st }}$ & $2^{\text {nd }}$ \\
\hline Control & $1.45 \mathrm{~d}$ & $1.03 \mathrm{de}$ & $0.21 \mathrm{~cd}$ & $0.39 \mathrm{~b}$ & $0.89 \mathrm{~b}$ & $0.88 c d$ \\
\hline E.E. 0.1 & $2.91 \mathrm{a}$ & $2.62 \mathrm{a}$ & $0.70 \mathrm{a}$ & $0.45 \mathrm{a}$ & $0.01 \mathrm{a}$ & $1.10 a$ \\
\hline E.E.0.15 & $1.47 \mathrm{~d}$ & $1.13 \mathrm{~d}$ & $0.15 \mathrm{de}$ & $0.32 \mathrm{c}$ & $1.04 \mathrm{a}$ & $1.10 a$ \\
\hline E.E. 0.2 & $1.55 \mathrm{c}$ & $1.42 \mathrm{c}$ & $0.10 \mathrm{e}$ & $0.09 \mathrm{e}$ & $0.86 \mathrm{~b}$ & $0.85 d$ \\
\hline Lyn. 1 & $1.86 \mathrm{~b}$ & $2.25 \mathrm{~b}$ & $0.15 \mathrm{de}$ & $0.27 \mathrm{~cd}$ & $1.01 \mathrm{a}$ & $0.92 c$ \\
\hline Lyn. 1.5 & $1.04 \mathrm{f}$ & $1.06 \mathrm{de}$ & $0.29 b$ & $0.23 \mathrm{~d}$ & $1.60 \mathrm{c}$ & $1.07 a$ \\
\hline E.E. $0.1+$ Lyn. 1 & $1.30 \mathrm{e}$ & $0.95 \mathrm{e}$ & $0.27 b c$ & $0.40 \mathrm{ab}$ & $1.90 \mathrm{~b}$ & $0.98 b$ \\
\hline LSDat 0.05 & 0.080 & 0.126 & 0.080 & 0.056 & 0.056 & 0.056 \\
\hline
\end{tabular}

\subsubsection{Potassium percentage (Table 6)}

In both seasons, two treatments showed significant increments above the control. They included the first and second treatments (ethinyl estradiol at $0.1 \mathrm{ppm}$ and at $0.15 \mathrm{ppm}$ ). In addition, the fourth treatment (lynestrenol at $1 \mathrm{ppm}$ ) in the first season, and the fifth treatment (lynestrenol at $1.5 \mathrm{ppm}$ ) in the second season, showed significant increments above the control. Other treatments in the two seasons were associated with irregular results (higher or lower) compared to the control.

\section{Anatomical features (Table 7)}

The second season results were submitted to statistical analysis, and are discussed below.

\subsection{Leaf blade parameters (See Figures 1-7) \\ 3.1.1.Laminar thickness $(\mu)$}

All hormone-containing drenches resulted in significant increments above the control. The first treatment ( $0.1 \mathrm{ppm}$ of ethinyl estradiol), was associated with the highest result (544 versus $464 \mu$ for the control). 


\subsubsection{Midrib thickness $(\mu)$}

The results in Table (7) demonstrate clearly significant increments associated with all hormonal treatments, in comparison to the control, with the first treatment (ethinyl estradiol at $0.1 \mathrm{ppm}$ ) being the most effective one (1328 $\mu$ compared to $704 \mu$ of the control). The result associated with this treatment was also significantly higher than those with all other hormonal doses.

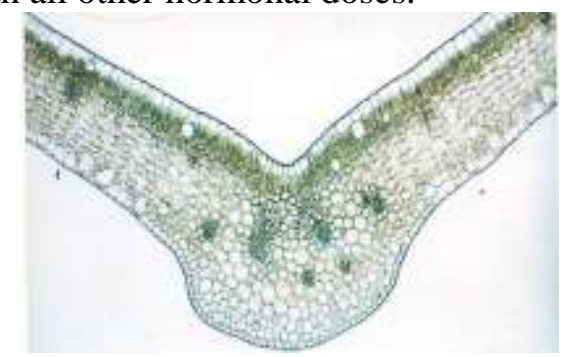

Fig.1: control plant

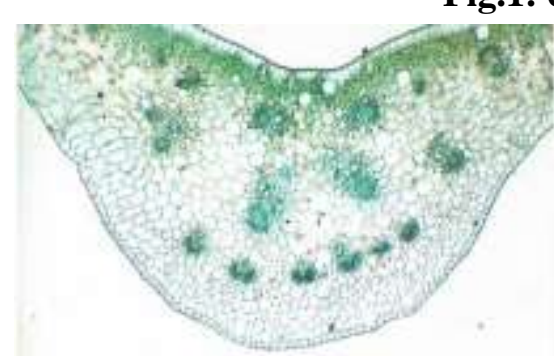

Fig.2: ethinyl estradiol, 0.1 ppm

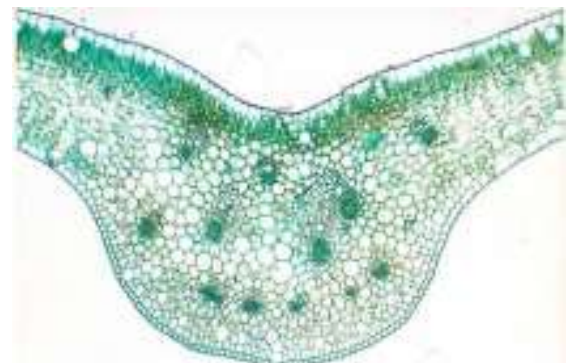

Fig.4: ethinyl estradiol, 0.2 ppm

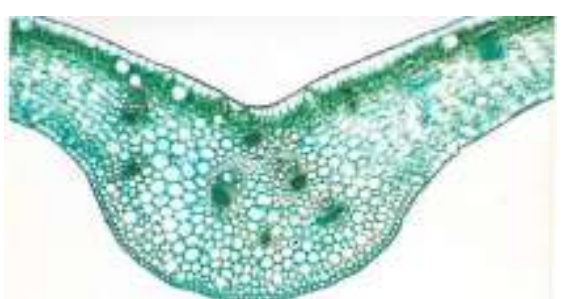

Fig.6: lynestrenol, 1.5 ppm

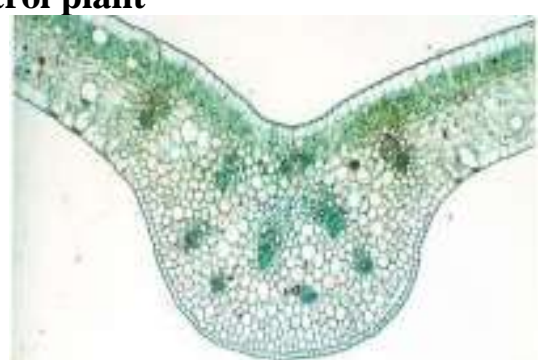

Fig.3: ethinyl estradiol, 0.15 ppm

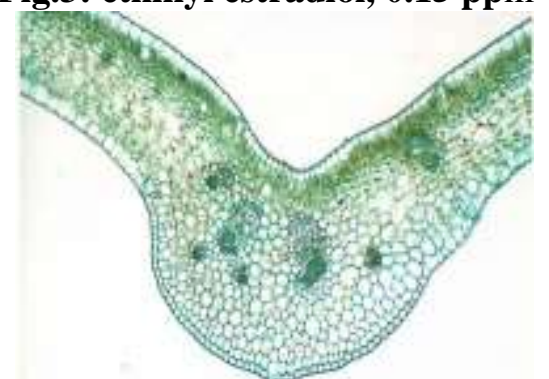

Fig.5: lynestrenol, 1 ppm

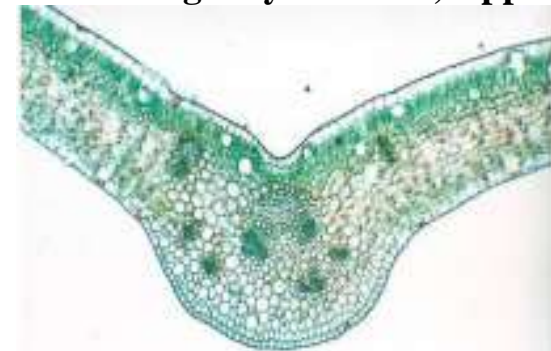

Fig.7: ethinyl estradiol, 0.1 ppm + lynestrenol, 1 ppm

Figures 1-7). Transverse sections (magnification X 40) in pothos leaves at the age of 200 days showing laminar thickness, midrib thickness and number of vascular bundles permidrib in control and plants treated with animal hormones 


\subsubsection{Number of vascular bundles per midrib}

All treatments induced significant increments except for the fourth treatment (lynestrenol at $1 \mathrm{ppm}$ ) which induced an insignificant rise. The most effective preparation was ethinyl estradiol at $0.1 \mathrm{ppm}$ that was also significantly higher than all other treatments. Its result was 2.5 times that of the control $(15$ versus 6 vascular bundles /midrib, respectively). Neovascularization (formation of additional vascular bundles) is thus clearly associated with the induced plant tissue growth, exactly as in the animal kingdom. This suggests the possibility of the presence of estrogen and/or progesterone receptors in the meristematic cells of the vascular cambium of pothos plant.

Table 7. Anatomical changes in blade and petiole of pothos leaves in response to animal hormones at the age of 200 days

\begin{tabular}{lccccc}
\hline Treatments & $\begin{array}{c}\text { Laminar } \\
\text { thickness }(\boldsymbol{\mu})\end{array}$ & $\begin{array}{c}\text { Midrib } \\
\text { thickness } \\
(\boldsymbol{\mu})\end{array}$ & $\begin{array}{c}\text { No.of } \\
\text { vascular } \\
\text { bundles } \\
\text { /midrib }\end{array}$ & $\begin{array}{c}\text { Petiole } \\
\text { thickness } \\
(\boldsymbol{\mu})\end{array}$ & $\begin{array}{c}\text { No. of } \\
\text { vascular } \\
\text { bundles } \\
\text { /petiole }\end{array}$ \\
\hline Control & $464 \mathrm{~b}$ & $704 \mathrm{~g}$ & $6 \mathrm{e}$ & $2368 \mathrm{~g}$ & $22 \mathrm{~d}$ \\
E.E.0.1 ppm & $544 \mathrm{a}$ & $1328 \mathrm{a}$ & $15 \mathrm{a}$ & $3920 \mathrm{a}$ & $48 \mathrm{a}$ \\
E.E.0.15 ppm & $480 \mathrm{~b}$ & $896 \mathrm{~d}$ & $10 \mathrm{c}$ & $3104 \mathrm{f}$ & $35 \mathrm{c}$ \\
E.E.0.2 ppm & $464 \mathrm{~b}$ & $1008 \mathrm{~b}$ & $13 \mathrm{~b}$ & $3568 \mathrm{c}$ & $38 \mathrm{~b}$ \\
Lyn.1 pm & $480 \mathrm{~b}$ & $848 \mathrm{e}$ & $7 \mathrm{de}$ & $3392 \mathrm{e}$ & $33 \mathrm{c}$ \\
Lyn.15 pm & $480 \mathrm{~b}$ & $928 \mathrm{c}$ & $8 \mathrm{~d}$ & $3520 \mathrm{~d}$ & $39 \mathrm{~b}$ \\
E.E.0.1 ppm+Lyn.1 pm & $480 \mathrm{~b}$ & $768 \mathrm{f}$ & $8 \mathrm{~d}$ & $3840 \mathrm{~b}$ & $46 a$ \\
\hline LSDat 0.05 & 27.07 & 30.430 & 1.779 & 27.070 & 2.161 \\
\hline
\end{tabular}

Means with different letters within each column are significant at $\mathrm{P}<0.05$ level and means without letters are not significant. LSD = Least significant difference No. $=$ Number $\quad$ E.E. $=$ Ethinyl estradiol $\quad$ Lyn. $=$ Lynestrenol

\subsection{Leaf petiole parameters (Table 7, Figures 8-14)}

\subsubsection{Thickness of petiole $(\mu)$}

All treatments gave significantly higher results, compared to the control, with ethinyl estradiol at $0.1 \mathrm{ppm}$, having a significantly higher result, than those of other treatments. The petiole thickness with this most effective treatment was $3920 \mu$ compared to $2368 \mu$ of the control.

\subsubsection{Number of vascular bundles per petiole}

A significant increment was recorded with all treatments, with the highest one being associated with the dose of ethinyl estradiol at $0.1 \mathrm{ppm}$, which was more than double that of the control (48 versus 22 vascular bundles per petiole). This again confirms the suggested concept of the development of neovascularization associated with stimulated plant tissue growth. Animal neovascularization or angiogenesis 


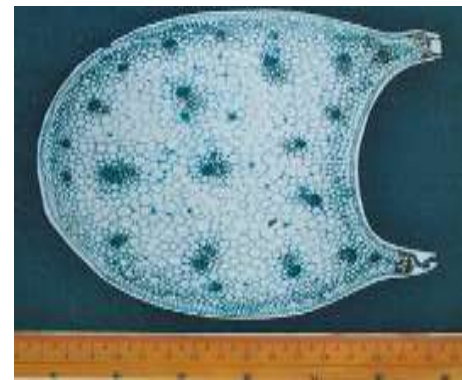

Fig 8: control plant
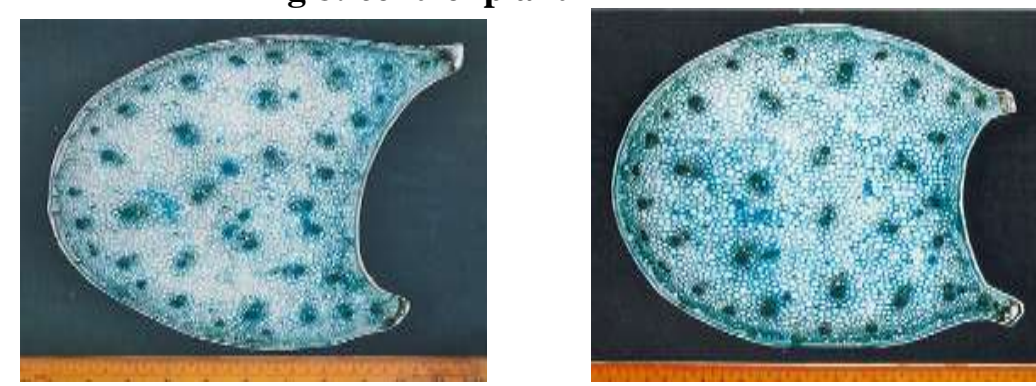

Fig.9:ethinyl estradiol, 0.1 ppm

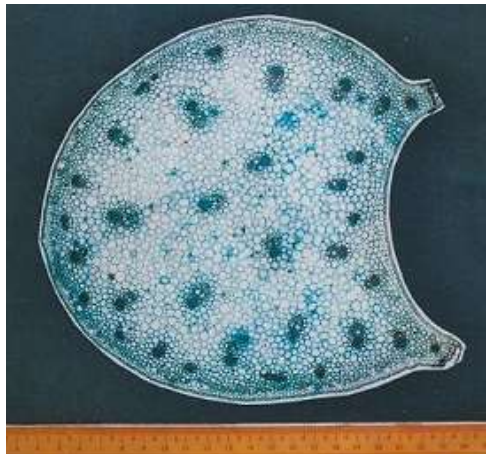

Fig.11: ethinyl estradiol, $0.2 \mathrm{ppm}$

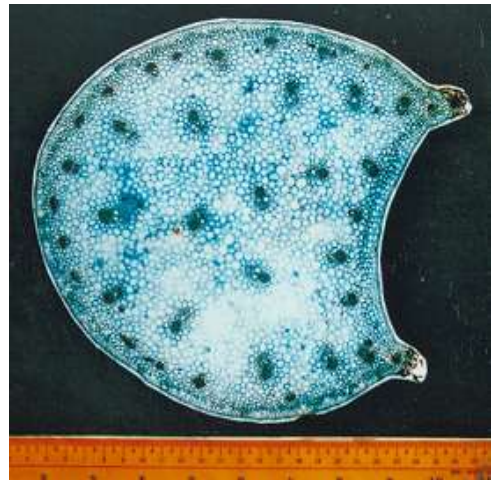

Fig.13: lynestrenol, 1.5 ppm
Fig.10:ethinyl estradiol, 0.15 ppm

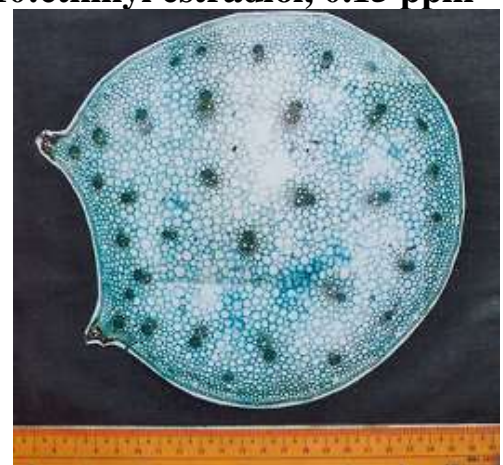

Fig.12: lynestrenol, 1 ppm

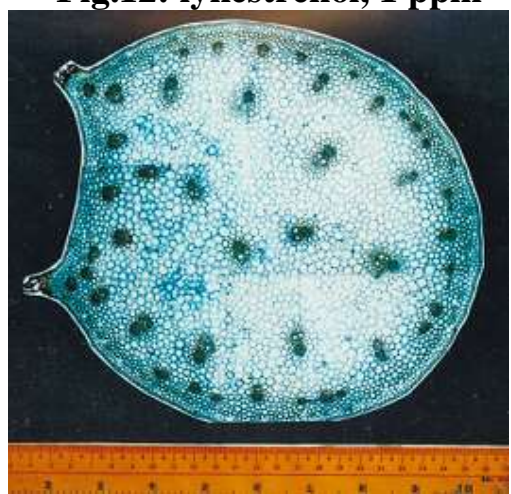

Fig.14: estrad, 0.1 ppm + lynestrenol, 1 ppm

Figures 8-14). Transverse sections (aggregated photograph) in pothos leaf petioles at the age of 200 days, showing petiole thickness and number of vascular bundles per petiole, in control and plants treated with animal hormones 
Development of additional vessels is mediated by different proteins, like angiogenin, associated with tissue proliferation (Karen et al, 1998).

A better realization of the increased biomass of the midrib, or of the petiole, is achieved via calculation of their cross-sectional areas via the following equation:

Surface area of a circle $=\pi r^{2}$

Where $\pi$ is the approximate ratio 3.14 and $\mathrm{r}$ is the radius.

The thickness of the midrib or petiole is used in this equation as being equal to $2 r$ (i.e. the diameter of the midrib or petiole).

The density of vascular bundles in the midrib, or in the petiole (number of bundles per unit area of the cross-section), can be calculated from the following equation:

Density of vascular bundles $=$ Number of vascular bundles in the structure

Cross-sectional area of the structure

The percentage increase in any of the parameters of the above-ground parts can be calculated from the following equation:

Percentage increase $=$

The mean value of treated plants - The mean value of control X 100

The mean value of control

Since the best results for the above-ground parts in this study were regularly recorded with ethinyl estradiol at $0.1 \mathrm{ppm}$, Table 8 shows the percentage increase in different anatomical parameters with this particular treatment.

As shown in Table (8), the cross-sectional area of the midrib (which indicates the degree of increase in midrib biomass), increased by $255.84 \%$. However, the density of vascular bundles in the midrib decreased in the plants which received the most effective treatment compared to the control (10.87 versus 15 vascular bundles/ $\mathrm{mm}^{2}$ ), while the total number of these bundles in a whole midrib was markedly increased in treated plants compared to the control (15 versus 6 bundles, with a percentage increase of $150 \%$ ).

Similarly, the cross-sectional area of the petiole increased by $174.04 \%$. However, the density of vascular bundles in the petiole decreased in the plants which received the most effective treatment compared to the control (3.98 versus 5 vascular bundles $/ \mathrm{mm}^{2}$ ), while the total number of these bundles in a whole petiole was markedly increased in treated plants compared to the control (48 versus 22 bundles, with a percentage increase of $118.18 \%$ ).

These findings show how much the thickness of these anatomical structures increases, while the associated increase in the number of feeding vascular bundles is at a lesser rate. A few more additional bundles can thus serve a much more additional biomass of plant tissue.

The anatomical changes described above, in addition to the morphological changes, confirm the clear response of the above-ground plant parts to hormonal treatment.

The presence of estrogen and progesterone receptors in the shoot organs, may thus be suggested in Scindapsus aureus (pothos) plant, with the estrogen receptors being more abundant. 
Table 8). Percentage increase in different anatomical parameters with ethinyl estradiol at $0.1 \mathrm{ppm}$, based on the mean values of control pothos plants.

\begin{tabular}{lccc}
\hline Character & Control & E.E. at 0.1 ppm & $\begin{array}{c}\text { Increase } \\
\%\end{array}$ \\
\hline Laminar thickness & $464 \mu$ & $544 \mu$ & 17.24 \\
\hline Midrib CSA & $\begin{array}{c}389059 \mu^{2} \\
\left(=0.39 \mathrm{~mm}^{2}\right)\end{array}$ & $\begin{array}{c}1384413 \mu^{2} \\
\left(=1.38 \mathrm{~mm}^{2}\right)\end{array}$ & 255.84 \\
\hline No. of vascular bundles / midrib & 6 & 15 & 150 \\
\hline Midrib vascular density & $6 \div 0.39=$ & $15 \div 1.38=$ \\
& $\left(15\right.$ V.B. $\left./ \mathrm{mm}^{2}\right)$ & $\left(10.87\right.$ V.B. $\left./ \mathrm{mm}^{2}\right)$ & \\
\hline Petiole CSA & $4401828 \mu^{2}$ & $12062624 \mu^{2}$ & 174.04 \\
& $\left(=4.40 \mathrm{~mm}^{2}\right)$ & $\left(=12.06 \mathrm{~mm}^{2}\right)$ & \\
\hline No. of vascular bundles / petiole & 22 & 48 & 118.18 \\
\hline Petiole vascular density & $22 \div 4.4=$ & $48 \div 12.06=$ & \\
& $\left(5\right.$ V.B. $\left./ \mathrm{mm}^{2}\right)$ & $\left(3.98\right.$ V.B. $\left./ \mathrm{mm}^{2}\right)$ & \\
\hline
\end{tabular}

CSA $=$ cross-sectional area V.B. $=$ vascular bundles No. $=$ number.

The presence of estrogen receptors in plants was previously confirmed by Lorena and Boland (2004). Animal organs demonstrate irregularity, as regards the presence of estrogen and progesterone receptors, with either of them being available in some tissues, and absent in others (Sylvia and Korach 2000). A possible alternative explanation to the recorded plant response to animal hormones is that, they may induce plant cytokinins, which are known in plant physiology to be responsible for morphogenesis (Marisa et al, 2005 and Michiko and Machida, 2006). A cytokinin-like action may be also exerted within the plant by these animal hormones or any of their degradation products.

\section{CONCLUSION}

From this study, it can be concluded that, female animal sex hormones, particularly estrogen, can represent exogenous biological growth regulators in the field of plant promotion. The results may also infer the possibility of the presence of progesterone receptors, beside the previously described, literature-documented estrogen receptors, in the plant kingdom.

Alternative possibilities are induction of plant cytokinins, or probably performing a cytokinin-like action by these animal hormones. According to this study, the following

Recommendations can be suggested:

1- Trying lower concentrations of both hormones 
2- Trying the same recommended estrogen concentration (ethinyl estradiol at $0.1 \mathrm{ppm}$ ) with different concentratons of different fertilizers.

3- Combining either of the two used zoochemical agents with any of the known phytochemical or chemical growth regulators, with holding comparisons versus either agent alone.

4- Studying the plant tissue content of the used animal hormones, or any of their degradation products, to have an idea about any possible phytotoxicity, in case of being used for increasing production of edible, medicinal or aromatic plants.

5- Comparing drenching to spraying as a method of application for the animal hormone, to explore the possibility of the presence of a bidirectional transport.

6- Performing a long-term study to evaluate the effect of animal hormones on the plant life time (persistence) and senescence. Shortterm trials may be possible with annual plants.

7- Trying the use of animal hormones in plant tissue cultures for induction of cellular proliferation.

\section{REFERENCES}

A.O.A.C. (1960). Official Methods of Analysis ( $9^{\text {th }}$ Ed.). Association of Official Analytical Chemists. Washington D.C., USA.

Dewis, J. and F. Freitas (1970): Physical and chemical methods of soil and water analysis. Food and Agric. Organization of the United Nations. Soil Bulletin No. 10.

Dirk K. H.; A.V. Popova and C. Cacela (2006): Chapter 6 Effects of Sugars on the Stability and Structure of Lipid Membranes during Drying. Advances in Planar Lipid Bilayers and Liposomes, 3:189217.

Karen A. O.; S. J. Verselis and J.W. Fett. (1998): Angiogenin Is Regulatedin Vivoas an Acute Phase Protein. Biochemical and Biophysical Research Communications, January; 242(3):480-483.

Lenka S.V.; E. Tylová; A. Soukup, H. Novická, O.Votrubová, H. Lipavská and H. Čížková. (2006): Influence of nutrient supply on growth, carbohydrate, and nitrogen metabolic relations in Typha angustifolia. Environmental and Experimental Botany, October; 57(3):246-257.

Lephart, E. D.; R. W. Rhees; K. D. R. Setchell; L. H. Bu and T. D. Lund (2003): Estrogens and phytoestrogens: brain plasticity of sexually dimorphic brain volumes. The Journal of Steroid Biochemistry and Molecular Biology, June 85(2-5):299-309. 
Lorena M. and R. Boland (2004): Presence of estrogen receptor (ER)-like proteins and endogenous ligands for ER in solanaceae. Plant Science, February, 166(2):397-404

Lourdes G. G. (2004): Plant perception systems for pathogen recognition and defence. Molecular Immunology, November, 41(11):10551062.

Marisa S. O.; K. J. Verbrugghe and A. R. Skop (2005): Midbodies and phragmoplasts: analogous structures involved in cytokinesis. Trends in Cell Biology, August, 15(8):404-413.

Mark J. C.; V. Vanoosthuyse and T. Gaude (2002): Receptor kinase signalling in plants and animals: distinct molecular systems with mechanistic similarities. Current Opinion in Cell Biology, April, 14(2):230-236.

Mathew T. M.; C.. M. Bula; J. E. Bishop and A. W. Norman (2005): A perspective on how the Vitamin D sterol/Vitamin D receptor (VDR) conformational ensemble model can potentially be used to understand the structure-function results of A-ring modified Vitamin D sterols. The Journal of Steroid Biochemistry and Molecular Biology, October, 97(1-2):69-82.

Michael R. D.; P. Anthony, J. B. Power and K. C. Lowe (2005): Plant protoplasts: status and biotechnological perspectives .Biotechnology Advances, March 23(2):131-171.

Michiko S. and Y. Machida. (2006): MAP65: a bridge linking a MAP kinase to microtubule turnover. Current Opinion in Plant Biology, December,

9(6):563-570.

Narry, V. K. and J.W. Nam (2006): Genomics of microRNA. Trends in Genetics, March; 22(3):165-173.

Peter V. B.; L. H. Filonova and M. F. Suarez (2005): Programmed Cell Death in Plant Embryogenesis. Current Topics in Developmental Biology, 67:135-179.

Reddy, K.V.R.; R.D. Yedery and C. Aranha (2004): Antimicrobial peptides: premises and promises. International Journal of Antimicrobial Agents, December, 24(6):536-547.

Saric, M.; R. Curi and T. Cupina (1976): chlorophyll determination. Univ. Unoven Sadu Par Ktikum is fiziologize Piljaka, Beogard, Hauncna, Anjiga, 215

Sass, J.E. (1961): Botanical Micro-Technique ( $3^{\text {rd }}$ Edit. Reprinted). Iowa State University Press Ames, 228.

Snedecor, G. W. and W. G., Cochran (1980): Statistical Methods, $6^{\text {Th }}$ ed., Iowa State Univ. Press, Iowa, U S A.

Steel, R. G. D. and J. H. Torrie (1981): Principles and Procedures of Statistics: A Biometrical Approach. $2^{\text {nd }}$ Ed. McGraw-Hill Book Co., New York, NY. 
Sylvia C. H. and K. S. Korach (2000): Progesterone action and responses in the $\alpha$ ERKO mouse. Steroids, October-November,65(10-11):551557.

Talmon, L.; M.Vega; B. Mujica and R. Boland (1989): Cytohistological studies on the action of vitamin $\mathrm{D}_{3}$ and stigmasterol on Phaseolus vulgaris roots growing in vitro. Plant Science, 59(2):183-190.

Tamás K.; Z. Kelemen; J. H. Waterborg and D. Dudits (2005): Short polypyrimidine /purine sequences modulate tissue-specific control of a cell cycle variant alfalfa histone $\mathrm{H} 3$ gene promoter. Plant Science, March, 68(3):789-795.

Torres S. (2002): Is exposure to endocrine disrupting compounds during fetal /post-natal development affecting the reproductive potential of farm animals? Domestic Animal Endocrinology, July, 23(1-2):203209.

Troug, E. and A. Meyer (1939): Improvement in deiness colorimetric method for phosphorus and arsenic. Ind. Eng. Chem. Anal. Ed. 1:136-139.

Willey, R.L. (1971): Micro technique: A: Laboratory Guide MacMillan Publishing Co., Inc., New York, 99.

Xiao L. and Y. Z. Zhang (2005): Computational detection of micro RNAs targeting transcription factor genes in Arabidopsis thaliana. Computational Biology and Chemistry, October, 29(5):360-367.

Yao T. W. and J. Y. Liu (2005): Molecular cloning and characterization of a cotton glucuronosyltranferase gene. Journal of Plant Physiology, May, 162 (5, 13):573-582.

Zhuang Z. and P. B. Mahajan (2005): Recombinant expression of maize nucleotide excision repair protein $\operatorname{Rad} 23$ in Escherichia coli. Protein Expression and Purification, June, 41(2):287-297. 


\title{
الهورمونات الحيوانية على الصفات المورفولوجية والكيميائية والتشريحية لنبات البوتوس (سيندابسس أورياس)
}

\author{
صفية حمدى محمود الحنفى الزئي \\ قسم بساتين الزينة ـ كلية الزراعة - جامعة القاهرة
}

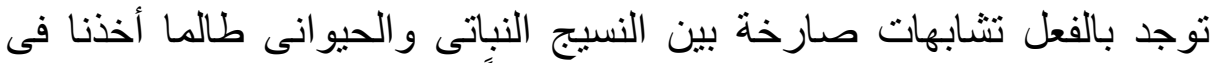

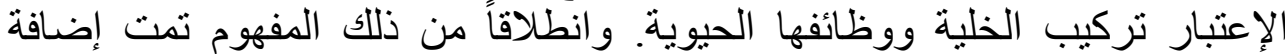

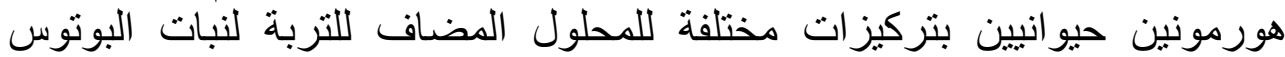

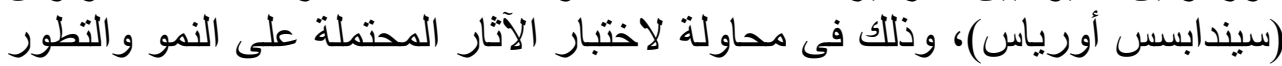

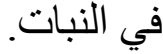

أجريت هذه التجربة بكلية الزر اعة - جامعة القاهرة ، خلال موسمين متعاقبين

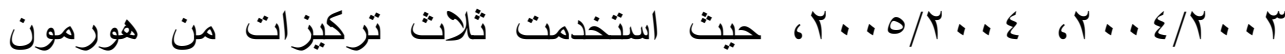

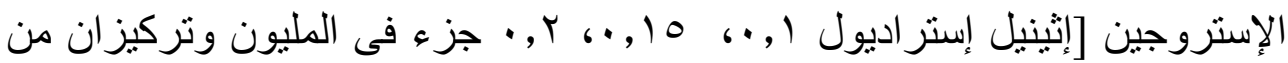

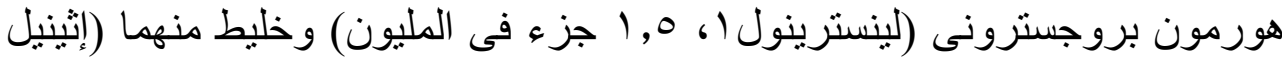
إستر اديول (, · + لينسترينول ( جزء في الملينون).

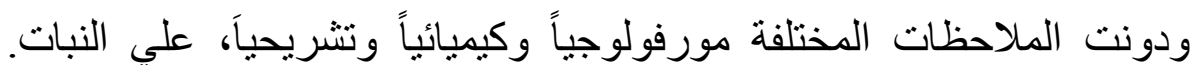

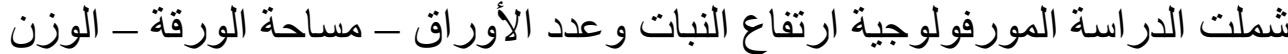

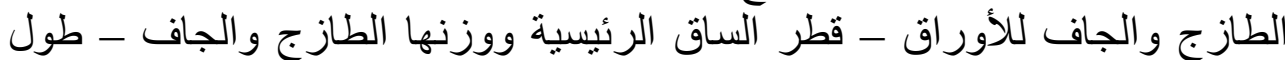

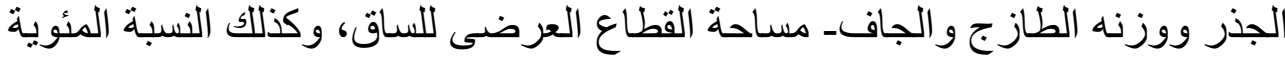

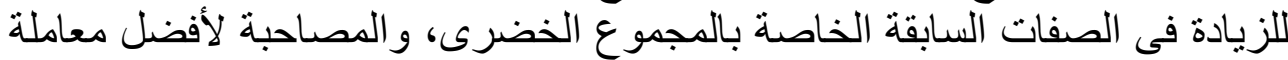

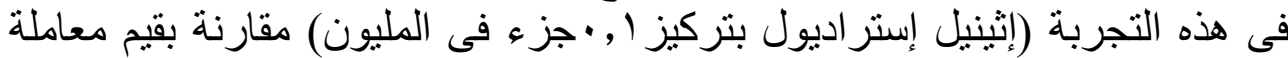

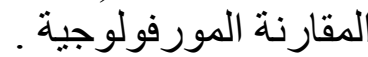

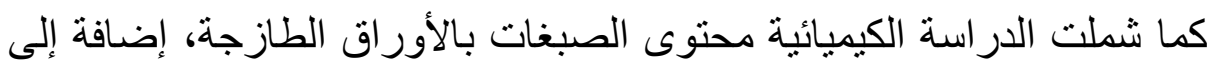

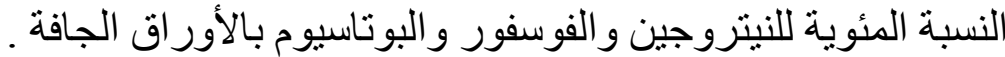

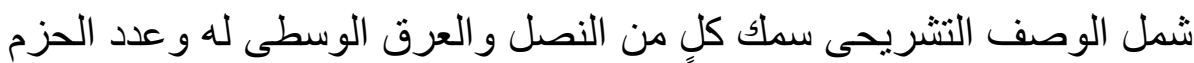

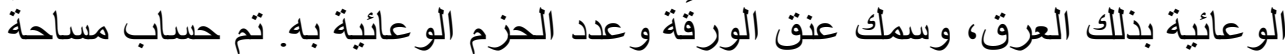

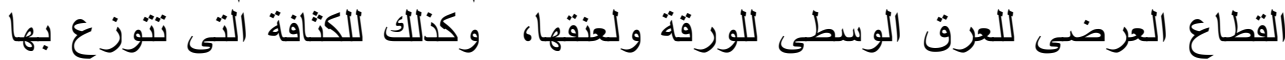

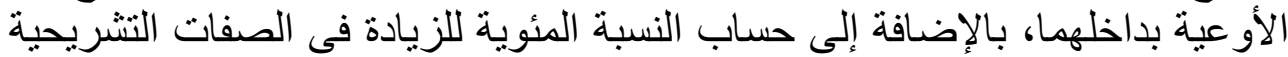

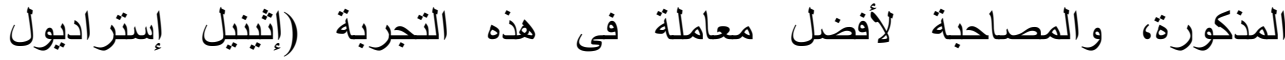
بتركيز ا , · جز ء فى المليون) مقارنة بقيم معاملة المقارنة التشريحية.

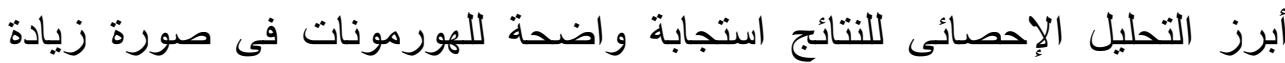

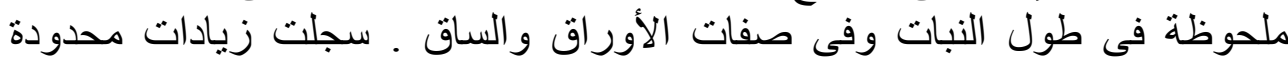

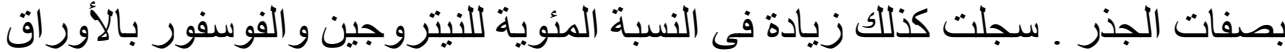


وبوجه عام فإن أفضل النتائج التحفيزية قد سجلت مع إثينيل إستر اديول

من ذلك يمكن استتناج أن الإستروجين قد يمثل شكلاً من منظمات النمات النمو الخارجية

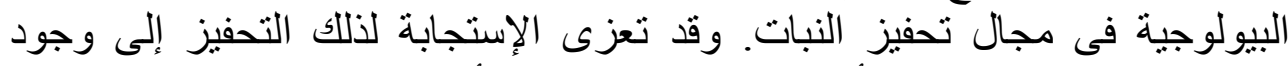

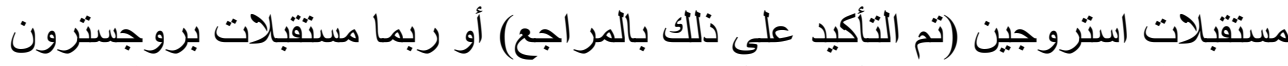

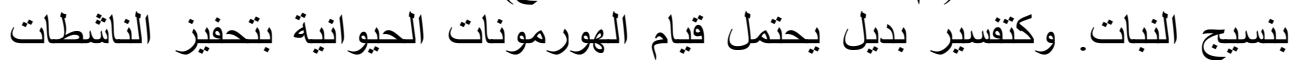

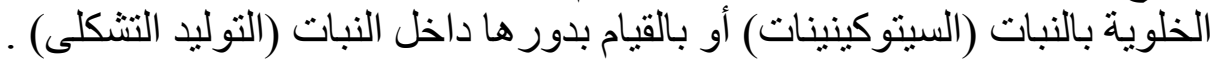

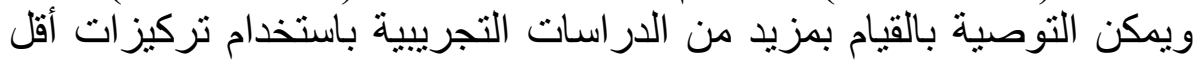

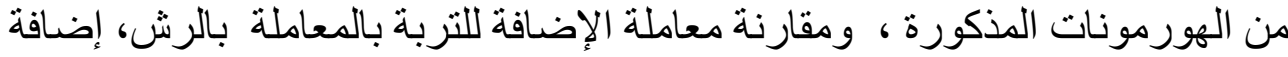

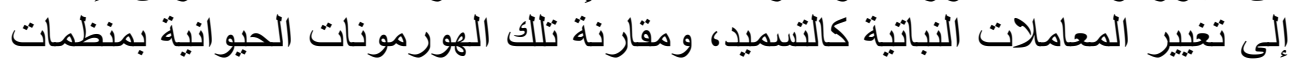

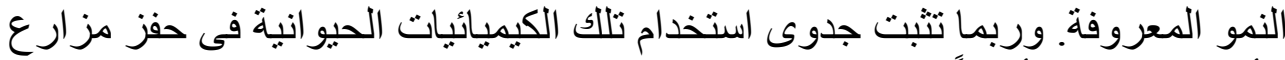

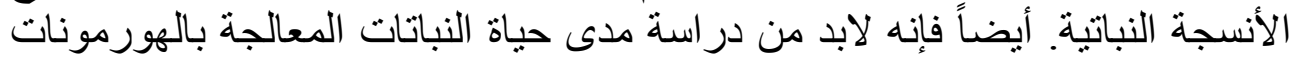

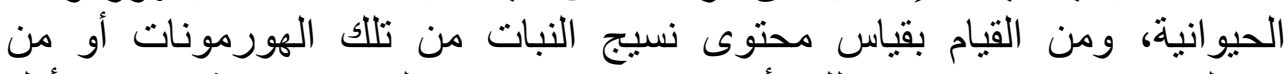

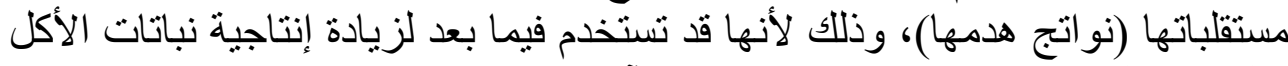

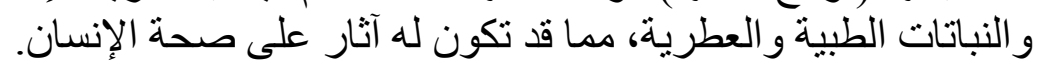

